\title{
PENGARUH PRODUCT, PRICE, POWER, DAN PUBLIC RELATION TERHADAP PENINGKATAN PENJUALAN MOTOR KAWASAKI PADA PT. DIANA INDONESIA MAKASSAR
}

\author{
MUHAMMAD SHALEH Z. \\ Universitas Sulawesi Barat \\ (E-mail: $\underline{\text { shalehzd@gmail.com) }}$
}

\begin{abstract}
ABSTRAK
Penelitian ini bertujuan: (a) Mengetahui dan menganalisis pengaruh faktor product, price, power, dan public relation terhadap peningkatan penjualan motor Kawasaki pada PT. Diana Indonesia Makassar, (b) Mengetahui faktor yang berpengaruh signifikan terhadap peningkatan penjualan motor Kawasaki pada PT. Diana Indonesia Makassar, dan (c) Menjadi bahan referensi dan strategi perusahaan dalam membuat rencana pemasaran dan strategi pemasaran yang handal pada masa yang akan datang.

Metode analisis yang dipergunakan ialah metode analisis deskriptif dan analisis Regresi Linier Berganda menggunakan program SPSS 22. Hasil penelitian ini menunjukkan hal-hal berikut ini. (a) Variabel product, price, power, dan public relation secara bersama-sama mempunyai pengaruh yang signifikan terhadap peningkatan penjualan motor Kawasaki pada PT. Diana Indonesia Makassar, (b) Variabel product dan power merupakan variabel yang berpengaruh signifikan terhadap peningkatan penjualan motor Kawasaki pada PT. Diana Indonesia Makassar, (c) Variabel price dan public relation merupakan variabel yang terkecil pengaruhnya terhadap peningkatan penjualan motor Kawasaki pada PT. Diana Indonesia Makassar, (d) Keempat variabel yang diteliti dengan metode analisis Regresi Linier Berganda menggunakan program SPSS 22 menghasilkan koefisien determinasi (R) sebesar 0.766 atau $76.6 \%$, (c) Metode analisis Regresi Linier Berganda ini mempunyai kemampuan dalam menjelaskan variasi naik turunnya variabel independen dan dependen, juga dapat menjelaskan semua variabel tersebut secara simultan dan parsial.
\end{abstract}

Kata Kunci : Product, Price, Power, Public Relation, dan Penjualan Motor Kawasaki.

\section{PENDAHULUAN}

\section{A. Latar Belakang}

Dengan berkembangnya Ilmu Pengetahuan dan Teknologi, maka semakin berkembang pula perusahaan-perusahaan industri, baik industri besar maupun industri kecil. Dengan demikian setiap perusahaan akan berlomba-lomba menerapkan ilmu pengetahuan dan teknologinya guna mendukung setiap produk yang dihasilkan dari perusahaan. Demikian pula perusahaan yang bergerak di bidang otomotif, mereka berperang melawan pesaing-pesaingnya guna merebut pasar, dengan keunggulan teknologi yang dimilikinya. Mereka berharap dengan teknologi maju dapat menciptakan produk-produk yang disukai dan dibutuhkan oleh konsumennya.

Kebutuhan masyarakat Indonesia akan alat transportasi kendaraan roda dua dewasa ini semakin bertambah. Perkembangan penjualan sepeda motor dari tahun ke tahun pun juga semakin meningkat. Ini menunjukan bahwa sepeda motor merupakan alat transportasi yang diminati oleh kalangan masyarakat. Disamping harganya lebih murah 
dibandingkan dengan harga mobil, dengan menggunakan sepeda motor pun masyarakat dapat lebih menghemat waktu.

Pergeseran nilai alat transportasi dari sepeda motor tentunya disebabkan perekonomian Indonesia makin baik sekarang ini, sehingga daya beli masyarakat semakin meningkat. Penggunaan sepeda motor tidak hanya sebatas kota-kota besar saja, namun sudah masuk ke daerah-daerah pedesaan. Keputusan untuk membeli tidak lagi terbatas pada orangtua saja, tetapi remaja pun sudah dapat menentukan tipe sepeda motor yang mereka ingin beli. Bahkan kelompok usia pembeli pun saat ini di dominasi oleh kalangan kaula muda. Hal ini tidaklah mengherankan karena dalam menjual sepeda motor banyak sekali menawarkan kemudahan-kemudahan seperti kredit jangka panjang, uang muka yang rendah, hadiah yang menarik atau pun juga dengan memberikan bunga yang rendah, sehingga pembeli dapat menyesuaikan kemampuannya dalam membeli sepeda motor.

PT Kawasaki Motor Indonesia (KMI) selaku pemegang merek Kawasaki di Indonesia optimis melihat pasar motor Indonesia di 2013. Produsen otomotif asal Jepang tersebut mengincar penjualan sepeda motornya di 2013 akan mencapai 160.000 unit atau naik $33,3 \%$ dibanding tahun lalu.

"Pada tahun 2012 lalu penjualan kita mencapai 120.000 unit," kata Freddyanto Basuki, Kepala Departemen Marketing dan Promosi PT KMI di Jakarta, Kamis (31/1/2013). Produsen yang memang fokus di segmen motor sport ini menargetkan pangsa pasar sebesar 2,5\% di tahun 2013. Di tahun 2012 sendiri, pangsa pasar Kawasaki baru $2 \%$.

Berdasarkan data Asosiasi Industri Sepeda Motor Indonesia (AISI) tahun 2012, total penjualan motor sport di pasar domestik mencapai 1.003.446 unit. Penjualan tersebut meningkat 17,6\% dibandingkan tahun 2011 lalu yang hanya mencapai 853.202 unit. Sebaliknya, total penjualan motor di Indonesia justru merosot hampir satu juta unit. Pada tahun 2012, total penjualan sepeda motor mencapai 7.064 .457 unit, turun $11,8 \%$ dibandingkan tahun 2011 yang berhasil menembus 8.012.540 unit.

Data AISI mencatat produsen Kawasaki penyumbang kontribusi terbesar motor sport tanah air sepanjang 2011 lalu. PT. Kawasaki Motor Indonesia (KMI) berhasil menjual 100.673 unit sepeda motor sepanjang tahun 2011. Berdasarkan data Asosiasi Industri Sepeda Motor Indonesia (AISI), perolehan penjualan itu merupakan angka pertumbuhan terbesar yakni $15,71 \%$ jika dibandingkan total penjualan KMI pada tahun sebelumnya yang mencapai 87.004 uni.

Pertumbuhan penjualan sepeda motor Kawasaki ini jauh melampaui pertumbuhan pasar motor nasional. Di mana Kawasaki menyumbangkan penjualan tinggi motor sport di tanah air, jika dilihat dari total penjualan sepeda motor yang tergabung dalam anggota AISI dengan pencapaian 8.043.535 unit tahun 2011. Indikasi itu menunjukkan pertumbuhan sebesar 8,7\% dari penjualan tahun lalu 7.398.644 unit.

Disebut ke dalam data AISI itu, bahwa segmen motor sport sebagai kontribusi terbesar, disumbangkan oleh tipe Kawasaki KLX 150S series dengan angka penjualan sebanyak 30.009 unit, Kawasaki Ninja 250R sebanyak 12.876 unit, serta Kawazaki Ninja 150 series yang terjual sebanyak 43.728 unit.

Keberhasilan pemasaran akan semakin meningkat apabila didukung oleh adanya suatu studi mengenai perilaku konsumen. Pada studi ini dikenal bahwa perilaku pembeli 
atau konsumen akan dipengaruhi oleh beberapa faktor, antara lain faktor intern dan faktor esktern, yang masing-masing dapat berperan dalam mempengaruhi perilaku konsumen.

Terdapat tiga pendekatan utama dalam meneliti perilaku konsumen. Pendekatan pertama adalah pendekatan interpretif. Pendekatan ini menggali secara mendalam perilaku konsumsi dan hal yang mendasarinya. Studi dilakukan dengan melalui wawancara panjang danfocus group discussion untuk memahami apa makna sebuah produk dan jasa bagi konsumen dan apa yang dirasakan dan dialami konsumen ketika membeli dan menggunakannya.

Pendekatan kedua adalah pendekatan tradisional yang didasari pada teori dan metode dari ilmu psikologi kognitif, sosial, dan behaviorial serta dari ilmu sosiologi. Pendekatan ini bertujuan mengembangkan teori dan metode untuk menjelaskan perilaku dan pembuatan keputusan konsumen. Studi dilakukan melalui eksperimen dan survey untuk menguji coba teori dan mencari pemahaman tentang bagaimana seorang konsumen memproses informasi, membuat keputusan, serta pengaruh lingkungan sosial terhadap perilaku konsumen.

Pendekatan ketiga disebut sebagai sains marketing yang didasari pada teori dan metode dari ilmu ekonomi dan statistika. Pendekatan ini dilakukan dengan mengembangkan dan menguji coba model matematika berdasarkan hirarki kebutuhan manusia menurut Abraham Maslow untuk memprediksi pengaruh strategi marketing terhadap pilihan dan pola konsumsi, yang dikenal dengan sebutan moving rate analysis.

Ketiga pendekatan sama-sama memiliki nilai dan tinggi dan memberikan pemahaman atas perilaku konsumen dan strategi marketing dari sudut pandang dan tingkatan analisis yang berbeda. Sebuah perusahaan dapat saja menggunakan salah satu atau seluruh pendekatan, tergantung permasalahan yang dihadapi perusahaan tersebut.

Terdapat 4 faktor internal yang relevan terhadap proses pembuatan keputusan pembelian, yaitu:

1. Produk (product), merupakan keputusan pembelian konsumen dengan melihat kualitas, penampilan, tambahan gaya, merek, pengepakan, ukuran, pelayanan, dan garansi;

2. Harga (price), merupakan keputusan pembelian konsumen dengan mempertimbangkan daftar harga rabat, pengecualian, periode, pembayaran, dan aturan, kredit;

3. Kekuatan (power), merupakan keputusan pembelian konsumen karena adanya faktor mengenali, membina hubungan dengan pihak-pihak yng memiliki pengaruh terhadap pasar;

4. Hubungan terhadap masyarakat (public relation), merupakan keputusan pembelian konsumen karena adanya komunikasi yang baik antara produsen dengan konsumen/pelanggan dan bagi produsen/penjual dengan memikirkan dan menciptakan berbagai cara pendekatan untuk bisa membangun image/citra yang baik terhadap produk dan jasa dikalangan masayarakat.

Berdasarkan uraian latar belakang tersebut di atas, maka sangat menarik diadakan suatu penelitian tentang "Pengaruh Product, Price, Power, dan Public Relation terhadap Peningkatan Penjualan Motor Kawasaki pada PT. Diana Indonesia Makassar." 


\section{B. Rumusan Masalah}

Berdasarkan latar belakang, maka masalah yang akan dikaji dalam penelitian ini dirumuskan: "Apakah product, price, power, dan public relation berpengaruh signifikan terhadap penjualan motor Kawasaki pada PT. Diana Indonesia Makassar?”

\section{B. Tujuan Penelitian}

1. Untuk menganalisis pengaruh product, price, power, dan public relation terhadap penjualan motor Kawasaki pada PT. Diana Indonesia Makassar.

2. Untuk menganalisis faktor yang dominan berpengaruh terhadap penjualan motor Kawasaki pada PT. Diana Indonesia Makassar.

\section{Hipotesis}

Berdasarkan rumusan masalah yang dikemukakan dalam penelitian ini maka diajukan beberapa hipotesis sebagai jawaban sementara , yaitu:

1. Faktor Product, Price, Power, dan Public Relation secara bersama-sama berpengaruh positif dan signifikan terhadap Penjualan Motor Kawasaki pada PT. Diana Indonesia Makassar.

2. Faktor Product dan Power berpengaruh dominan terhadap Penjualan Motor Kawasaki pada PT. Diana Indonesia Makassar.

\section{METODE PENELITIAN}

Populasi dalam penelitian ini adalah seluruh pelanggan PT. Diana Indonesia Makassar yang membeli serta menggunakan sepeda motor merek Kawasaki. Di mana jumlah unit kendaraan motor kawasaki yang terjual dari tahun 2011 sampai tahun 2013 sebanyak 31851 unit dengan rincian tahun 2011 berjumlah 8863 unit, tahun 2012 berjumlah 11515 unit, dan tahun 2013 berjumlah 11473 unit. Jumlah sampel yang diambil sebanyak 50 responden yang terdapat dalam populasi tersebut.

Data-data penelitian dikumpulkan dengan cara observasi, wawancara, kuesioner, dan dokumentasi. Analisis data dilakukan secara deskriptif untuk faktor-faktor yang berpengaruh terhadap penjualan motor Kawasaki pada PT. Diana Indonesia Makassar.

Selanjutnya dilakukan analisis regresi berganda untuk menguji hipotesis yang telah dikemukakan dengan menggunakan Uji Simultan (Uji F) dan Uji Parsial (Uji t).

Uji F ini dilakukan untuk melihat pengaruh variabel-variabel independen secara keseluruhan terhadap variabel dependen. Uji t ini dilakukan untuk melihat signifikan dari pengaruh independen secara individu terhadap variabel dependen dengan menganggap variabel lain bersifat konstan.

\section{HASIL PENELITIAN DAN PEMBAHASAN}

\section{A. Analisis Perkembangan Penjualan}

Penjualan merupakan fungsi penting dalam pemasaran, karena penjualan yang maksimum adalah merupakan sasaran yang ingin dicapai oleh perusahaan. Fungsi penjualan juga merupakan sumber pendapatan yang diperlukan untuk menutupi biaya 
dengan harapan bisa memperoleh keuntungan dari hasil penjualan tersebut. Oleh karena itu setiap perusahaan akan berusaha maksimal agar barang atau jasa yang diproduksinya dapat terjual secara maksimum. Peningkatan hasil penjualan produksi adalah merupakan salah satu ukuran keberhasilan perusahaan dalam memasarkan produk yang dihasilkan.

Penganalisaan ini dimaksudkan untuk mengetahui perkembangan perusahaan apakah mengalami kemajuan atau tidak, sekaligus faktor-faktor yang berpengaruh di dalamnya. Oleh sebab itu, peningkatan jumlah hasil penjualan produk dari tahun 2011 dapat dijadikan sebagai salah satu bahan utama guna penyelidikan sampai seberapa jauh rencana pemasaran itu telah dilaksanakan. Selanjutnya berdasarkan analisa ini, manajemen diharapkan dapat lebih mengembangkan perusahaannya yaitu dengan menambah volume penjualan melalui cara-cara tertentu, seperti dengan meningkatkan promosi, cara pelayanan, dan lain-lain.

Tabel 1. Perkembangan Penjualan Motor Kawasaki (Unit) Tahun 2011-2013

\begin{tabular}{|c|c|c|c|}
\hline \multirow{2}{*}{ Tahun } & \multirow{2}{*}{ Tingkat Penjualan (Unit) } & \multicolumn{2}{|c|}{ Perkembangan Pertahun } \\
\cline { 3 - 4 } & & (Unit) & $(\%)$ \\
\hline 2011 & 8863 & - & - \\
2012 & 11515 & 2652 & 23.03 \\
2013 & 11473 & -42 & -0.36 \\
\hline
\end{tabular}

Sumber: PT. Diana Indonesia, Perkembangan di analisis oleh peneliti.

Pada Tabel 1, tingkat penjualan motor Kawasaki pada PT. Diana Indonesia terlihat bahwa dari tahun ke tahun menunjukkan total kenaikannya tidak tetap misalnya pada tahun 2011 jumlah tingkat penjualan motor Kawasaki mencapai 8863 unit kendaraan, pada tahun 2012 mengalami peningkatan penjualan sebesar 11515 unit dengan tingkat persentase sebesar 23.03 persen, sedangkan pada tahun 2013 mengalami penurunan penjualan kendaraan sebesar 11473 unit kendaraan dengan tingkat persentase sebesar 0.36 persen, dimana jumlah penjualannya menurun tidak terlalu signifikan.

Dengan melihat pada perkembangan jumlah tingkat penjualan motor Kawasaki pada PT. Diana Indonesia yang merupakan Main Dealer Motor Kawasaki, dari persentase perkembangan setiap tahunnya terlihat bahwa pada tahun 2011 sampai tahun 2013 menunjukkan tingkat persentase penjualannya adalah rata-rata 7.55 persen.

\section{B. Deskripsi Variabel Penelitian}

\section{Variabel Penjualan Motor Kawasaki}

Tabel 2. Rekapitulasi Jawaban Responden terhadap Variabel Penjualan Motor Kawasaki

\begin{tabular}{|c|c|c|c|c|c|c|c|c|c|c|}
\hline \multirow[b]{2}{*}{ No. } & \multirow[b]{2}{*}{ Nilai } & \multirow[b]{2}{*}{ Kategori } & \multicolumn{2}{|c|}{$Y_{1.1}$} & \multicolumn{2}{|c|}{$Y_{1.2}$} & \multicolumn{2}{|c|}{$\mathbf{Y}_{1.3}$} & \multicolumn{2}{|c|}{$\mathbf{Y}_{1.4}$} \\
\hline & & & $\mathbf{N}$ & $\%$ & $\mathbf{N}$ & $\%$ & $\mathbf{N}$ & $\%$ & $\mathbf{N}$ & $\%$ \\
\hline 1 & 1 & Tidak berpengaruh & & & & & & & & \\
\hline 2 & 2 & Kurang berpengaruh & & & 4 & 4 & 4 & 4 & & \\
\hline 3 & 3 & Cukup berpengaruh & 4 & 4 & 2 & 2 & 6 & 6 & 3 & 3 \\
\hline 4 & 4 & Berpengaruh & 16 & 16 & 23 & 23 & 20 & 20 & 18 & 18 \\
\hline 5 & 5 & Sangat berpengaruh & 30 & 30 & 21 & 21 & 20 & 20 & 29 & 29 \\
\hline & & Total & 50 & 50 & 50 & 50 & 50 & 50 & 50 & 50 \\
\hline
\end{tabular}

Sumber: Data Primer yang diolah. 
Pada indikator pertama mengenai kondisi dan kemampuan penjual, ada 4 responden (4\%) yang menyatakan cukup berpengaruh, 16 responden (16\%) menyatakan berpengaruh, dan 30 responden (30\%) menyatakan sangat berpengaruh. Berdasarkan uraian tersebut, menunjukkan bahwa PT. Diana Indonesia berhasil dalam menjual produknya dalam kondisi yang sangat baik.

Indikator kedua mengenai kondisi pasar (target pasar) sebelum melakukan transaksi penjualan, terdapat 4 responden (4\%) yang menyatakan kurang berpengaruh, 2 responden (2\%) menyatakan cukup berpengaruh, 23 responden (23\%) menyatakan berpengaruh, dan 21 responden (21\%) menyatakan sangat berpengaruh. Hal ini menunjukkan bahwa kondisi pasar yang merupakan sasaran penjualan PT. Diana Indonesia merupakan tempat yang pas atau cocok untuk melakukan transaksi karena kebutuhan masyarakat akan kendaraan motor Kawasaki sangat tinggi. Selain itu, target pasar yang merupakan sasaran penjualannya merupakan tempat yang strategis dan competitor atau pesaing yang ada di area tersebut masih kurang.

Indikator ketiga mengenai modal dalam memasarkan produk motor Kawasaki. Dari hasil Tabel 2, terdapat 4 responden (4\%) menyatakan kurang berpengaruh, 6 responden (6\%) menyatakan cukup berpengaruh, 20 responden $(20 \%)$ menyatakan berpengaruh, dan 20 responden (20\%) menyatakan sangat berpengaruh. Berdasarkan uraian tersebut, dapat dikatakan bahwa modal yang dibutuhkan PT. Diana Indonesia dalam memasarkan produknya dan melakukan pemeliharaan kendaraan sangat baik.

Indikator keempat mengenai kondisi perusahaan. Dari hasil jawaban responden yang diperoleh terdapat 3 responden (3\%) menyatakan cukup berpengaruh, 18 responden (18\%) menyatakan berpengaruh, dan 29 responden (29\%) menyatakan sangat berpengaruh. Berdasarkan uraian tersebut, dapat dikatakan bahwa kondisi perusahaan baik dalam hal penjualan, pemeliharaan, dan pembiayaan produk dalam pemasarannya sangat baik dan ditangani oleh karyawan yang berpengalaman di bidangnya.

\section{Variabel Produk (Product)}

Variabel produk merupakan salah satu variabel independen pada penelitian ini, dimana pada variabel produk ini terdapat empat indikator yang dipakai sebagai pengukuran.

Tabel 3. Rekapitulasi Jawaban Responden terhadap Variabel Produk

\begin{tabular}{|c|c|c|c|c|c|c|c|c|c|c|}
\hline \multirow[b]{2}{*}{ No. } & \multirow[b]{2}{*}{ Nilai } & \multirow[b]{2}{*}{ Kategori } & \multicolumn{2}{|c|}{$\mathbf{X}_{1.1}$} & \multicolumn{2}{|c|}{$\mathbf{X}_{1.2}$} & \multicolumn{2}{|c|}{$\mathbf{X}_{1.3}$} & \multicolumn{2}{|c|}{$\mathbf{X}_{1.4}$} \\
\hline & & & $\mathbf{N}$ & $\%$ & $\mathbf{N}$ & $\%$ & $\mathbf{N}$ & $\%$ & $\mathbf{N}$ & $\%$ \\
\hline 1 & 1 & Tidak sesuai & & & & & & & & \\
\hline 2 & 2 & Kurang sesuai & & & & & & & & \\
\hline 3 & 3 & Cukup sesuai & 8 & 8 & 14 & 14 & 17 & 17 & 2 & 2 \\
\hline 4 & 4 & Sesuai & 15 & 15 & 14 & 14 & 27 & 27 & 40 & 40 \\
\hline 5 & 5 & Sangat sesuai & 27 & 27 & 22 & 22 & 6 & 6 & 8 & 8 \\
\hline & & Total & 50 & 50 & 50 & 50 & 50 & 50 & 50 & 50 \\
\hline
\end{tabular}

Sumber: Data Primer yang diolah.

Indikator pertama mengenai pernyataan konsumen terhadap kualitas/mutu yang dimiliki oleh produk motor Kawasaki yang dipasarkan oleh PT. Diana Indonesia, pada 
Tabel 3, menunjukkan bahwa ada 8 responden (8\%) yang menyatakan cukup sesuai, 15 responden (15\%) menyatakan sesuai, dan 27 responden (27\%) menyatakan sangat sesuai. Dari uraian tersebut dapat dikatakan bahwa sebahagian besar konsumen menyatakan kualitas/mutu yang dimiliki oleh produk motor Kawasaki sangat baik atau dengan kata lain mereka beranggapan bahwa kendaraan motor Kawasaki yang mereka beli sesuai dengan kebutuhan konsumen.

Indikator yang kedua mengenai pernyataan konsumen terhadap fitur produk yang ditawarkan, pada Tabel 3, menunjukkan bahwa ada 14 responden (14\%) yang menyatakan cukup sesuai, 14 responden (14\%) yang menyatakan sesuai, dan 22 responden (22\%) yang menyatakan sangat sesuai. Dari uraian tersebut diketahui sebagian besar konsumen menyatakan dan beranggapan sangat sesuai terhadap fitur yang terdapat pada produk yang ditawarkan oleh PT. Diana Indonesia.

Indikator ketiga mengenai tanggapan konsumen terhadap desain produk, berdasarkan hasil rekapitulasi jawaban responden, diketahui ada 17 responden (17\%) yang menyatakan cukup sesuai, 27 responden (27\%) yang menyatakan sesuai, dan 6 responden $(6 \%)$ yang menyatakan sangat sesuai. Dari uraian tersebut diketahui sebagian besar konsumen menyatakan dan beranggapan sesuai terhadap desain produk motor Kawasaki. Hal ini disebabkan desain produk tersebut sangat menarik bagi mereka sudah sesuai dengan harapan mereka.

Indikator keempat mengenai tanggapan konsumen terhadap ciri-ciri produk, berdasarkan hasil rekapitulasi jawaban responden, diketahui ada 2 responden (2\%) yang menyatakan cukup sesuai, 40 responden (40\%) yang menyatakan sesuai, dan 8 responden (8\%) yang menyatakan sangat sesuai. Dari uraian tersebut diketahui sebagian besar konsumen menyatakan dan beranggapan sesuai terhadap ciri-ciri yang terdapat pada produk motor Kawasaki yang dapat membedakan dengan produk dari perusahaan atau organisasi lain yang juga bergerak di bidang penjualan kendaraan bermotor roda dua. Hal ini disebabkan ciri-ciri produk tersebut bagi mereka sudah sesuai dengan harapan konsumen.

\section{Variabel Harga (Price)}

Variabel harga merupakan salah satu variabel independen pada penelitian ini, dimana pada variabel harga ini terdapat empat indikator yang dipakai sebagai pengukuran.

Tabel 4. Rakapitulasi Jawaban Responden terhadap Variabel Harga

\begin{tabular}{|c|c|c|c|c|c|c|c|c|c|c|}
\hline \multirow[b]{2}{*}{ No. } & \multirow[b]{2}{*}{ Nilai } & \multirow[b]{2}{*}{ Kategori } & \multicolumn{2}{|c|}{$\mathbf{X}_{2.1}$} & \multicolumn{2}{|c|}{$\mathbf{X}_{2.2}$} & \multicolumn{2}{|c|}{$\mathbf{X}_{2.3}$} & \multicolumn{2}{|c|}{$\mathbf{X}_{2.4}$} \\
\hline & & & $\mathbf{N}$ & $\%$ & $\mathbf{N}$ & $\%$ & $\mathbf{N}$ & $\%$ & $\mathbf{N}$ & $\%$ \\
\hline 1 & 1 & Tidak sesuai & & & 2 & 2 & & & & \\
\hline 2 & 2 & Kurang sesuai & & & 4 & 4 & & & & \\
\hline 3 & 3 & Cukup sesuai & 7 & 7 & 24 & 24 & 15 & 15 & 9 & 9 \\
\hline 4 & 4 & Sesuai & 16 & 16 & 20 & 20 & 28 & 28 & 20 & 20 \\
\hline 5 & 5 & Sangat sesuai & 27 & 27 & - & - & 7 & 7 & 21 & 21 \\
\hline \multicolumn{3}{|c|}{ Total } & 50 & 50 & 50 & 50 & 50 & 50 & 50 & 50 \\
\hline
\end{tabular}

Sumber: Data Primer yang diolah. 
Indikator pertama mengenai metode cost-plus pricing, dari Tabel 4, terlihat ada 7 responden (7\%) yang menyatakan cukup sesuai, 16 responden (16\%) menyatakan sesuai, dan 27 responden $(27 \%)$ menyatakan sangat sesuai.

Indikator kedua mengenai tanggapan konsumen terhadap metode mark-up pricing, dari Tabel 4 . diketahui ada 2 responden (2\%) menyatakan tidak sesuai, 4 responden (4\%) menyatakan kurang sesuai, 24 responden (24\%) menyatakan cukup sesuai, dan 20 responden (20\%) menyatakan sesuai.

Indikator ketiga mengenai tanggapan konsumen terhadap metode break-even pricing, dari Tabel 4. diketahui ada 15 responden (15\%) menyatakan cukup sesuai, 28 responden (28\%) menyatakan sesuai, dan 7 responden (7\%) menyatakan sangat sesuai. Indikator keempat mengenai penetapan harga dalam hubungan dengan pasar, dari hasil rekapitulasi jawaban responden terlihat bahwa ada 9 responden (9\%) yang menyatakan cukup sesuai, 20 responden (20\%) menyatakan sesuai, dan 21 responden (21\%) menyatakan sangat sesuai. Hal ini dapat berarti bahwa konsumen setuju akan harga jual yang diberlakukan oleh perusahaan sebagaimana sudah sangat sesuai dengan produk yang ditawarkan dan ini juga dapat berarti bahwa produk motor Kawasaki sangat diterima oleh konsumen pada pangsa pasar.

\section{Variabel Power (Kekuasaan)}

Variabel power (kekuasaan) merupakan salah satu variabel independen pada penelitian ini, di mana pada veriabel power ini terdapat empat indikator yang dipakai sebagai pengukuran.

Tabel 5. Rekapitulasi Jawaban Responden terhadap Variabel Power

\begin{tabular}{|c|c|l|c|c|c|c|c|c|c|c|}
\hline & \multirow{2}{*}{ No. } & \multirow{2}{*}{ Nilai } & \multicolumn{1}{|c|}{ Kategori } & \multicolumn{2}{|c|}{$\mathbf{X}_{\mathbf{3 . 1}}$} & \multicolumn{2}{c|}{$\mathbf{X}_{\mathbf{3 . 2}}$} & \multicolumn{2}{|c|}{$\mathbf{X}_{\mathbf{3 . 3}}$} & \multicolumn{2}{|c|}{$\mathbf{X}_{\mathbf{3 . 4}}$} \\
\cline { 3 - 10 } & $\mathbf{N}$ & $\mathbf{\%}$ & $\mathbf{N}$ & $\mathbf{\%}$ & $\mathbf{N}$ & $\mathbf{\%}$ & $\mathbf{N}$ & $\mathbf{\%}$ \\
\hline 1 & 1 & Tidak berpengaruh & & & & & & & & \\
2 & 2 & Kurang berpengaruh & & & & & & & & \\
3 & 3 & Cukup berpengaruh & 6 & 6 & 3 & 3 & 3 & 3 & 10 & 10 \\
4 & 4 & Berpengaruh & 22 & 22 & 17 & 17 & 22 & 22 & 18 & 18 \\
5 & 5 & Sangat berpengaruh & 22 & 22 & 30 & 30 & 25 & 25 & 22 & 22 \\
\hline \multicolumn{2}{|c|}{} & Total & 50 & 50 & 50 & 50 & 50 & 50 & 50 & 50 \\
\hline
\end{tabular}

Sumber: Data Primer yang diolah.

Indikator pertama mengenai tanggapan responden terhadap competence (kompetensi) atau kemampuan interpersonal dan komunikasi yang efektif, dari Tabel 5. terlihat ada 6 responden (6\%) yang menyatakan cukup berpengaruh, 22 responden (22\%) menyatakan berpengaruh, dan 22 responden (22\%) menyatakan sangat berpengaruh. Dari uraian tersebut dapat diketahui bahwa sebahagian besar responden menyatakan dan beranggapan bahwa dengan adanya power marketing dalam suatu perusahaan dapat sangat berpengaruh dan membantu dalam peningkatan penjualan suatu produk.

Indikator kedua mengenai tanggapan responden terhadap customer, dari Tabel 5. diketahui ada 3 responden (3\%) yang menyatakan cukup berpengaruh, 17 responden (17\%) menyatakan berpengaruh, dan 30 orang (30\%) menyatakan sangat berpengaruh. Dari hasil uraian tersebut dapat diketahui bahwa sebahagian besar responden menyatakan 
dan beranggapan bahwa dengan adanya customer dalam suatu pemasaran dan penjualan suatu produk berarti memperlakukan pelanggan sebagai raja dan menganggap kegiatan pemasaran adalah kegiatan konsultasi.

Indikator ketiga mengenai tanggapan responden terhadap competition, dari Tabel 5. diketahui ada 3 responden (3\%) yang menyatakan cukup berpengaruh, 22 responden (22\%) menyatakan berpengaruh, dan 25 responden (25\%) yang menyatakan sangat berpengaruh. Dari uraian tersebut dapat diketahui bahwa sebahagian besar konsumen menyatakan dan beranggapan bahwa jika perusahaan dapat menyampaikan segala sesuatu mengenai produknya secara kompetitif dalam citra dan dapat bergerak cepat dalam menyampaikan produknya kepada konsumen dari perusahaan lain berarti dapat cepat mempengaruhi dan mempromosikan produknya secara langsung kepada konsumen. Jadi dapat disimpulkan bahwa competition merupakan salah satu faktor penentu dalam menentukan peningkatan penjualan suatu produk.

Indikator keempat mengenai tanggapan responden terhadap convenience yang diterapkan oleh PT. Diana Indonesia, dari Tabel 5. diketahui ada 10 responden (10\%) yang menyatakan cukup berpengaruh, 18 responden (18\%) menyatakan berpengaruh, dan ada 22 responden (22\%) menyatakan sangat berpengaruh. Berdasarkan uraian tersebut dapat disimpulkan bahwa sebahagian responden menyatakan dan beranggapan bahwa dengan adanya convenience yang berarti aturan dasar dalam penyampaian adalah bagaimana agar pelanggan atau konsumen merasa nyaman terhadap perlakuan perusahaan dalam memasarkan dan menjual suatu produk yang ditawarkan, khususnya oleh PT. Diana Indonesia dalam menawarkan kendaraan motor Kawasaki kepada konsumen.

\section{Variabel Public Relation}

Variabel Public Relation merupakan salah satu variabel independen pada penelitian ini, dimana pada variabel Public Relation ini terdapat 4 (empat) indikator yang dipakai sebagai pengukuran.

Tabel 6. Rekapitulasi Jawaban Responden terhadap Variabel Public Relation

\begin{tabular}{|c|c|c|c|c|c|c|c|c|c|c|}
\hline \multirow[b]{2}{*}{ No. } & \multirow[b]{2}{*}{ Nilai } & \multirow[b]{2}{*}{ Kategori } & \multicolumn{2}{|c|}{$\mathbf{X}_{4.1}$} & \multicolumn{2}{|c|}{$\mathbf{X}_{4.2}$} & \multicolumn{2}{|c|}{$\mathbf{X}_{4.3}$} & \multicolumn{2}{|c|}{$\mathbf{X}_{4.4}$} \\
\hline & & & $\mathbf{N}$ & $\%$ & $\mathbf{N}$ & $\%$ & $\mathbf{N}$ & $\%$ & $\mathbf{N}$ & $\%$ \\
\hline 1 & 1 & Tidak mudah & & & & & & & & \\
\hline 2 & 2 & Kurang mudah & 4 & 4 & 5 & 5 & 4 & 4 & 4 & 4 \\
\hline 3 & 3 & Cukup mudah & 15 & 15 & 23 & 23 & 17 & 17 & 15 & 15 \\
\hline 4 & 4 & Mudah & 18 & 18 & 22 & 22 & 20 & 20 & 27 & 27 \\
\hline 5 & 5 & Sangat mudah & 13 & 13 & - & - & 9 & 9 & 4 & 4 \\
\hline \multicolumn{3}{|c|}{ Total } & 50 & 50 & 50 & 50 & 50 & 50 & 50 & 50 \\
\hline
\end{tabular}

Sumber: Data Primer yang diolah.

Indikator pertama mengenai tanggapan responden terhadap communicator atau penghubung antara organisasi dengan konsumen, dari Tabel 6. diketahui ada 4 responden (4\%) yang menyatakan kurang mudah, 15 responden (15\%) yang menyatakan cukup mudah, 18 responden (18\%) menyatakan mudah, dan 13 responden (13\%) yang menyatakan sangat mudah. 
Indikator kedua mengenai tanggapan responden terhadap relationship, dari Tabel 6. diketahui ada 5 responden (5\%) yang menyatakan kurang mudah, 23 responden (23\%) menyatakan cukup mudah, dan 22 responden (22\%) yang menyatakan mudah. Dari uraian tersebut dapat disimpulkan bahwa sebagian besar responden menyatakan mudah mendapatkan motor Kawasaki dengan relationship yang baik dan saling menguntungkan antara perusahaan dengan pihak konsumen.

Indikator ketiga mengenai tanggapan responden terhadap peranan back-up management, dari Tabel 6. diketahui ada 4 responden (4\%) yang menyatakan kurang mudah, 17 responden (17\%) menyatakan cukup mudah, 20 responden (20\%) yang menyatakan mudah, dan ada 9 responden (9\%) yang menyatakan sangat mudah. Dari uraian tersebut dapat disimpulkan bahwa sebagian besar responden menyatakan mudah mendapatkan perhatian dan merangsang konsumen untuk membeli motor Kawasaki yang dibutuhkan dengan adanya manajemen perusahaan yang berfungsi dengan baik dan berperan sesuai dengan tugasnya masing-masing.

Indikator keempat mengenai tanggapan responden terhadap corporate image, dari Tabel 6. diketahui ada 4 responden (4\%) yang menyatakan kurang mudah, 15 responden (15\%) menyatakan cukup mudah, 27 responden (27\%) yang menyatakan mudah, dan ada 4 responden (4\%) yang menyatakan sangat mudah. Dari uraian tersebut dapat disimpulkan bahwa sebagian besar responden menyatakan mudah mendapatkan perhatian dan merangsang konsumen untuk membeli motor Kawasaki yang dibutuhkan dengan jalan membentuk corporate image yang artinya bagaimana peranan public relations berupaya menciptakan citra bagi organisasi atau lembaganya terhadap masyarakat luas di mana lebih difokuskan kepada konsumen pengguna motor Kawasaki.

\section{Analisis Regresi dan Korelasi}

Analisis regresi dan korelasi dimaksudkan untuk menguji seberapa besar pengaruh Produk, Harga, Power, dan Publik Relation terhadap Penjualan Motor Kawasaki pada PT. Diana Indonesia, sehingga dalam penelitian ini dapat diberikan regresi yaitu sebagai berikut: $Y=a_{0}+b_{1} X_{1}+b_{2} X_{2}+b_{3} X_{3}+b_{4} X_{4}+e$. Adapun output data hasil regresi linier dapat dilihat pada Tabel 7.

Tabel 7. Hasil Analisis Regresi dan Korelasi

\begin{tabular}{|c|c|c|c|c|c|c|}
\hline \multicolumn{7}{|c|}{$\mathrm{Y}=28.030+1.285 \mathrm{X}_{1}+0.097 \mathrm{X}_{2}+1.252 \mathrm{X}_{3}+0.056 \mathrm{X}_{4}$} \\
\hline \multirow{5}{*}{\multicolumn{2}{|c|}{$\begin{array}{l}\text { Koefisien Korelasi (R) } \\
\text { Koefisien Determinasi }\left(\mathrm{R}^{2}\right) \\
\text { Adjusted R Square } \\
\text { F Hitung } \\
\text { Sig, Simultan }\end{array}$}} & \multirow{5}{*}{\multicolumn{5}{|c|}{$\begin{array}{l}=0.766 \\
=0.587 \\
=0.551 \\
=16.004 \\
=0.000\end{array}$}} \\
\hline & & & & & & \\
\hline & & & & & & \\
\hline & & & & & & \\
\hline & & & & & & \\
\hline \multirow[t]{2}{*}{ Model } & \multicolumn{2}{|c|}{$\begin{array}{l}\text { Unstandartdized } \\
\text { Coefficients }\end{array}$} & $\begin{array}{c}\text { Standartdized } \\
\text { Coefficients }\end{array}$ & \multirow[t]{2}{*}{$\begin{array}{c}\mathrm{T} \\
\text { hitung }\end{array}$} & \multirow[t]{2}{*}{ Sig. } & \multirow[t]{2}{*}{ Kep. } \\
\hline & B & $\begin{array}{l}\text { Std. } \\
\text { Error }\end{array}$ & Beta & & & \\
\hline Konstanta & 28.030 & 7.468 & & 3.754 & 0.000 & \\
\hline Product $\left(\mathrm{X}_{1}\right)$ & 1.285 & 0.163 & 0.798 & 7.860 & 0,000 & Signifikan \\
\hline Price $\left(\mathrm{X}_{2}\right)$ & 0.097 & 0.149 & 0.067 & 0.652 & 0.517 & Tdk Signifikan \\
\hline Power $\left(X_{3}\right)$ & 1.252 & 0.347 & 0.370 & 3.611 & 0.001 & Signifikan \\
\hline Public Relation $\left(\mathrm{X}_{4}\right)$ & 0.056 & 0.088 & 0.064 & 0.631 & 0.532 & Tdk Signifikan \\
\hline
\end{tabular}

Sumber: Data primer setelah diolah tahun 2014. 
Berdasarkan hasil olahan data uji regresi, secara statistik setidaknya dapat diukur dengan nilai determinasi dan nilai statistik F. Nilai koefisien determinasi adalah antara nol (0) dan satu (1). Nilai Adjusted $R^{2}$ yang kecil berarti kemampuan variabel-variabel dependen amat terbatas. Nilai yang mendekati satu berarti variabel-variabel independen memberikan hampir semua informasi yang dibutuhkan untuk memprediksi variabelvariabel dependen (Ghozali, 2005:83). Dari hasil penelitian diperoleh nilai Adjusted $\mathrm{R}^{2}=0.587$ dan $\mathrm{F}_{\text {hitung }}=16.004$ sehingga model regresi yang akan disajikan dalam memprediksi produktivitas sudah tepat atau fit.

Selanjutnya berdasarkan hasil analisis regresi dan korelasi di atas, apabila diinterpresetasikan dapat memberikan analisa sebagai berikut:

1. Nilai konstanta sebesar 28.030 menunjukkan bahwa apabila variabel independen konstan atau sama dengan nol maka penjualan motor Kawasaki meningkat sebesar 28.030 .

2. Besarnya nilai koefisien regresi variabel Product $\left(\mathrm{X}_{1}\right)$ adalah 1.285 yang menunjukkan bahwa jika variabel Product meningkat 1\% maka akan meningkatkan penjualan motor Kawasaki sebesar 1.285 atau $128.5 \%$ dengan asumsi bahwa variabel lain seperti Price, Power, dan Public Relation berada dalam keadaan konstan atau sama dengan nol. Koefisien bernilai positif artinya terjadi hubungan positif antara Product dengan Penjualan Motor Kawasaki, semakin naik Product maka semakin meningkatkan penjualan motor Kawasaki.

3. Besarnya nilai koefisien regresi variabel Price $\left(\mathrm{X}_{2}\right)$ adalah 0.097 yang menunjukkan bahwa jika variabel Price meningkat 1\%, maka akan meningkatkan penjualan motor Kawasaki sebesar 0.097 atau 9.7\% dengan asumsi bahwa variabel lain seperti Product, Power, dan Public Relation berada dalam keadaan konstan atau sama dengan nol. Koefisien bernilai positif artinya terjadi hubungan positif antara Price dengan Penjualan Motor Kawasaki, semakin naik Price maka semakin meningkatkan penjualan motor Kawasaki.

4. Besarnya nilai koefisien regresi variabel Power $\left(\mathrm{X}_{3}\right)$ adalah 1.252 yang menunjukkan bahwa jika variabel Power meningkat 1\% maka akan meningkatkan penjualan motor Kawasaki sebesar 1.252 atau $125.2 \%$ dengan asumsi bahwa variabel lain seperti Product, Price, dan Public Relation berada dalam keadaan konstan atau sama dengan nol. Koefisien bernilai positif artinya terjadi hubungan positif antara Power dengan Penjualan Motor Kawasaki, semakin naik Power maka semakin meningkatkan penjualan motor Kawasaki.

5. Besarnya nilai koefisien regresi variabel Public Relation $\left(\mathrm{X}_{4}\right)$ adalah 0.056 yang menunjukkan bahwa jika variabel Public Relation meningkat $1 \%$ maka akan meningkatkan penjualan motor Kawasaki sebesar 0.056 atau $5.6 \%$ dengan asumsi bahwa variabel lain seperti Product, Price, dan Power berada dalam keadaan konstan atau sama dengan nol. Koefisien bernilai positif artinya terjadi hubungan positif antara Public Relation dengan Penjualan Motor Kawasaki, semakin naik Public Relation maka semakin meningkatkan penjualan motor Kawasaki.

6. Nilai koefisien korelasi (R) sebesar 0.766 yang menunjukkan bahwa hubungan antara variabel independen yaitu Product $\left(\mathrm{X}_{1}\right)$, Price $\left(\mathrm{X}_{2}\right)$, Power $\left(\mathrm{X}_{3}\right)$, dan Public 
Relation $\left(\mathrm{X}_{4}\right)$ terhadap variabel dependen yaitu Penjualan Motor Kawasaki (Y) berkorelasi positif atau mempunyai hubungan yang sangat kuat.

Nilai koefisien determinasi $\left(\mathrm{R}^{2}\right)$ sebesar 0.587 yang menunjukkan bahwa $\left(\mathrm{R}^{2}\right)$ memberikan pengaruh variabel independen terhadap variabel dependen sebesar 0.587 atau $58.7 \%$ dan sisanya sebesar $41.3 \%$ dipengaruhi oleh variabel lain yang tidak diteliti dalam penelitian ini. Atau variabel independen yang digunakan dalam model dapat memberikan penjelasan $100 \%$ variasi variabel dependen.

$\mathbf{U j i}-\mathbf{F}$

Analisis uji $\mathrm{F}$ dilakukan untuk melihat secara simultan pengaruh variabel independen $\left(\mathrm{X}_{1}, \mathrm{X}_{2}, \mathrm{X}_{3}\right.$, dan $\left.\mathrm{X}_{4}\right)$ terhadap variabel dependen $(\mathrm{Y}) . \mathrm{F}_{\text {tabel }}\left(\alpha=0,05: \mathrm{df}_{1}=\right.$ $\left.(\mathrm{k}+1)-1=4 ; \mathrm{df}_{2}=\mathrm{n}-(\mathrm{k}+1)=45\right) \mathrm{F}_{\text {tabel }}=2.578$. Dari olah data diperoleh nilai $\mathrm{F}_{\text {hitung }}$ sebesar 16.004 dengan nilai probabilitas $(\mathrm{sig})=0,000$. Nilai $\mathrm{F}_{\text {hitung }}(16.004)>\mathrm{F}_{\text {tabel }}$ (2.578) dan tingkat signifikansi 0,000 < 0,05 yang berarti bahwa variabel Product, Price, Power, dan Public Relation secara bersama-sama berpengaruh positif dan signifikan terhadap Penjualan Motor Kawasaki pada PT. Diana Indonesia. Dengan demikian hipotesis pertama (H1) diterima, dalam arti variabel independen mempunyai pengaruh terhadap variabel dependen.

Uji $-\mathbf{t}$

Analisis uji t dilakukan untuk melihat dan mengukur secara parsial pengaruh masing-masing variabel independen $\left(\mathrm{X}_{1}, \mathrm{X}_{2}, \mathrm{X}_{3}\right.$, dan $\left.\mathrm{X}_{4}\right)$ terhadap variabel dependen $(\mathrm{Y})$, dengan hasil sebagai berikut:

1. Product $\left(\mathrm{X}_{1}\right)$ terhadap Penjualan Motor Kawasaki (Y)

Untuk variabel Product $\left(\mathrm{X}_{1}\right)$, nilai $\mathrm{t}_{\text {hitung }}(7.860)>\mathrm{t}_{\text {tabel }}$ (2.014) dengan tingkat signifikansi 0,000 lebih kecil dari 0,05 berarti Product berpengaruh signifikan terhadap Penjualan Motor Kawasaki.

2. Price $\left(\mathrm{X}_{2}\right)$ terhadap Penjualan Motor Kawasaki (Y)

Untuk variabel Price $\left(\mathrm{X}_{2}\right)$, nilai $\mathrm{t}_{\text {hitung }}(0.652)<\mathrm{t}_{\text {tabel }}(2.014)$ dengan tingkat signifikansi 0.517 lebih besar dari 0,05 berarti Price berpengaruh tidak signifikan terhadap Penjualan Motor Kawasaki.

3. Power $\left(\mathrm{X}_{3}\right)$ terhadap Penjualan Motor Kawasaki (Y)

Untuk variabel Power $\left(\mathrm{X}_{3}\right)$, nilai $\mathrm{t}_{\text {hitung }}(3.611)>\mathrm{t}_{\text {tabel }}$ (2.014) dengan tingkat signifikansi 0,001 lebih kecil dari 0,05 berarti Power berpengaruh signifikan terhadap Penjualan Motor Kawasaki.

4. Public Relation $\left(\mathrm{X}_{4}\right)$ terhadap Penjualan Motor Kawasaki (Y)

Untuk variabel Public Relation $\left(\mathrm{X}_{4}\right)$, nilai $\mathrm{t}_{\text {hitung }}(0.631)>\mathrm{t}_{\text {tabel }}(2.014)$ dengan tingkat signifikansi 0.532 lebih besar dari 0,05 berarti Public Relation berpengaruh tidak signifikan terhadap Penjualan Motor Kawasaki.

Berdasarkan uji-t di atas menunjukkan bahwa secara parsial variabel independen yaitu Product, Price, Power, dan Public Relation berpengaruh terhadap Penjualan Motor Kawasaki pada PT. Diana Indonesia. Sedangkan variabel Price dan Public Relation berpengaruh tidak signifikan terhadap Penjualan Motor Kawasaki. 
Berdasarkan tabel di atas, dapat dilihat bahwa nilai beta terbesar adalah Product dengan nilai beta 1.285, artinya variabel Product merupakan variabel yang paling berpengaruh terhadap Penjualan Motor Kawasaki. Dengan kata lain variabel Product berpengaruh dominan terhadap Penjualan Motor Kawasaki. Hal ini membuktikan bahwa hipotesis kedua (H2) yang menyatakan variabel Product berpengaruh dominan terhadap Penjualan Motor Kawasaki pada PT. Diana Indonesia dari pada Price dan Public Relation, diterima.

\section{PENUTUP}

Berdasarkan hasil penelitian maka ada beberapa kesimpulan yang dapat ditarik, yaitu:

1. Hipotesis pertama $(\mathrm{H} 1)$ yang menyatakan bahwa variabel bauran pemasaran yang terdiri dari Product, Price, Power, dan Public Relation secara bersama-sama mempunyai pengaruh yang signifikan terhadap Penjualan Motor Kawasaki pada PT. Diana Indonesia Makassar, berdasarkan hasil analisis Full Model Regression terbukti kebenarannya. Hal ini ditujukkan oleh nilai $\mathrm{F}_{\text {hitung }}$ sebesar 16.004 yang nilainya lebih besar dari nilai $\mathrm{F}_{\text {tabel }}$ sebesar 2.578 atau (16.004 > 2.578).

2. Dari hasil perhitungan regresi untuk variabel Produk menunjukkan pengaruh yang paling dominan terhadap konsumen dalam melakukan keputusan pembelian, sedangkan variabel Produk dan Power berpengaruh signifikan terhadap peningkatan penjualan motor Kawasaki.

3. Dari hasil perhitungan diperoleh nilai t-hitung untuk variabel Harga sebesar 0.652 dan variabel Publik Relation sebesar 0.631 di mana kedua variabel tersebut nilainya lebih kecil dari t-tabel sebesar 2.014. Angka ini menunjukkan bahwa hubungan variabel Harga dan Publik Relation terhadap Penjualan Motor Kawasaki tidak signifikan, artinya bahwa walaupun variabel Harga dan Publik Relation ditingkatkan atau mengalami penurunan terhadap Penjualan Motor Kawasaki tidak terlalu banyak mempengaruhi atau pengaruhnya tidak signifikan terhadap keputusan konsumen dalam pembelian motor Kawasaki dan terhadap peningkatan penjualan motor Kawasaki.

4. Ada beberapa alasan mengapa faktor Produk menentukan keputusan konsumen dalam memilih untuk membeli motor Kawasaki, yaitu:

a. Produk motor Kawasaki mempunyai image/citra yang tinggi bagi pemiliknya sehingga individu yang menggunakan motor Kawasaki mempunyai kebanggaan tersendiri.

b. Selain image, motor Kawasaki juga mempunyai kualitas atau mutu produk yang baik dibandingkan dengan sebagian produksi kendaraan bermotor roda dua dari perusahaan yang lain.

c. Motor Kawasaki juga mempunyai model kendaraan yang bergaya dan inovatif.

Oleh karena itulah maka pihak PT. Diana Indonesia betul-betul memperhatikan faktor Produk dalam memasarkan dan menjual produknya dan mengandalkan kekuatan atau power dalam melakukan pemasaran dan penjualan di segmen pasarnya. 


\section{DAFTAR PUSTAKA}

Boone \& Kurtz. 2002. Pengantar Bisnis. Jakarta: Penerbit Erlangga.

Cutlip-Center-Broom. 2006. Effective Public Relations, Eight Edition, Prentice Hall International, Inc.

Cutlip-Center-Broom. 2009. Effective public Relations, edisi kesembilan. Jakarta: Kencana Prenada Media Group.

Efendi, Fakpahan \& Makhfudli. 2009. Keperawatan Komunitas Teori dan Praktik dalam Keperawatan. Jakarta: Salemba Medika.

Effendi, Onong Uchjiana. 2002. Hubungan Masyarakat Suatu Studi Komunikologi. Bandung: Remadja Rosdakarya.

Handoko, T. Hani. 2000. Dasar-Dasar Manajemen Produksi dan Operasi. Yogyakarta: BPFE.

Hansen dan Mowen. Terjemahan. Ancella A Hermawan. 2001. Akuntansi Manajemen. Jakarta: Erlangga.

Kotler, Philip. 2000. Manajemen Pemasaran. Terjemahan. Hendra Teguh dan Rony A Rusly. Jakarta: Prehalindo.

Kotler, Philip. 2002. Manajemen Pemasaran. Alih Bahasa. Hendra Teguh, Edisi Milenium I. Jakarta: Prenhalindo.

Kotler, Philip. 2003. Marketing Management, 11th edition, Prentice Hall, New Jersey.

Kotler, Philip. 2004. Manajemen Pemasaran Edisi Kesebelas. Jilid 2. Jakarta: Indeks.

Kotler, Philip dan Amstrong. 2004. Prinsip-prinsip Marketing, Edisi Ketujuh. Jakarta: Salemba Empat.

Kotler, Philip dan Armstrong, Gary. 2005. Prinsip-prinsip Pemasaran. Jilid Kedua, Edisi Kedelapan. Jakarta: Penerbit Erlangga.

Mulyadi. 2001. Sistem Akuntansi. Yogyakarta: STIE YKPN.

Mulyana, Dedy. 2000. Ilmu Komunikasi, Pengantar. Bandung: Remaja Rosadakarya.

Saputra, Wahidin dan Rully Nasrullah. 2011. Public Relations 2.0 (Teori dan Praktik Public Relations di Era Cyber). Jakarta: Gramata Publishing.

Stanton, William J. 2000. Prinsip-prinsip Pemasaran. Jakarta: Erlangga.

Stanton, William J. 2001. Prinsip-prinsip Pemasaran. Jilid Ketujuh. Jakarta: Erlangga.

Sugiyono. 2009. Metode Penelitian Bisnis. Bandung: Alfabeta.

Sukirno, Sadono. 2006. Mikro Ekonomi Teori Pengantar. Edisi Ketiga. Jakarta: Rajagrafindo Persada.

Swastha, Basu. 2000. Pengantar Bisnis Modern, Pengantar Ekonomi Perusahaan Modern. Jakarta: Liberty.

Swastha, Basu. 2004. Azas-azas Marketing. Yogyakarta: Liberty.

Swastha, Basu. 2005. Asas-asas marketing, Yogyakarta: Liberty.

Tjiptono, Fandy. 2001. Strategi Promosi. Yogyakarta: Andi.

Tjiptono, Fandy. 2008. Strategi Pemasaran. Edisi Ketiga. Yogyakarta: Andi. 